\title{
TESTING CS-0.2 CLOVER THRESHER AND SCARIFIER FEATURING IMPROVED DRUM DESIGN
}

\author{
Aleksandr Burkov ${ }^{1}$, Maksim Simonov ${ }^{2}$, Valentin Mokiyev ${ }^{1}$, Viktor Lazykin ${ }^{1}$ \\ ${ }^{1}$ Federal Agricultural Research Center of the North-East named N.V. Rudnitsky, Russia; \\ ${ }^{2}$ Vyatka State University, Russia \\ burkov.46@mail.ru, simaksim@mail.ru,dizel154@bk.ru, ellestar@bk.ru
}

\begin{abstract}
The paper dwells upon the design and process of CS-0.2, an improved clover thresher and scarifier. The deck has a blind oval threshing surface and consists of cylindrical steel rods. The drum has a solid threshing surface made of hexagonal rolled steel rods mounted upright. The rods have triangular-profile transverse grooves. The grooves have sharpened edges to better crush clover pods and the hard surface of Galega orientalis (eastern galega) seeds. Experiments were designed to find how the depth of such transverse grooves and the drum rotation speed could affect the quality of seed threshing and scarification. At a feed of $250 \mathrm{~kg} \cdot \mathrm{h}^{-1}$ with the allowed seed crushing rate being set to $1.5 \%$, the best clover seed sieving performance was attained using 2.0...2.8 mm deep grooves with the drum rotating at $1,545 \ldots 1,575 \mathrm{~min}^{-1}$, while the best eastern galega seed scarification performance was attained at $2.5 \ldots 3.5 \mathrm{~mm}$ and $840 \ldots 890 \mathrm{~min}^{-1}$. Thanks to the grooves in the threshing surface of the drum, the unit performs well when threshing or scarifying legume seeds, while its core design is unchanged. For either process, the optimal groove depth is $2.5 \mathrm{~mm}$; the best drum rotation speed is 1,550 $\mathrm{min}^{-1}$ for threshing, $850 \mathrm{~min}^{-1}$ for scarification. The improved design features better performance, while also reducing the specific costs of seed treatment.
\end{abstract}

Keywords: clover thresher and scarifier, drum, threshing surface, transverse grooves, threshing, scarification of seeds.

\section{Introduction}

Perennial herbs are an important source of feed for livestock; besides, they enhance the soil structure and keep it fertile [1-3]. To improve seed quality and quantity, harvested heaps are threshed, and the hard seeds are scarified (i.e. their solid shells are crushed) before seeding [4-7]. Short-term use of special machinery (i.e. KT-250, K-0.7, or MVS-05.000 clover threshers [8-10], or SS-0.5, SKS-1, SK-300 scarifiers $[11 ; 12]$ ) is not cost-effective. To reduce the specific costs of legume seed treatment, the Federal Agrarian Research Center in Northeast designed its own CS- 0.2 clover thresher and scarifier, which can perform both threshing and scarification before seeding [13]. The cylindrical drum rotates around a horizontal axis and has a solid threshing surface. The surface is made of hexagonal steel rods. The rods are mounted upright with respect to the cylindrical surface. The deck has a blind threshing surface of cylindrical steel rods and wraps around the drum below. Thanks to smooth threshing surface of the drum and deck the machine minimizes seed damage and is highly reliable. For the same reason its most important flaw is the underperformance in threshing wet hulls for seeds, or in scarifying hard legume seeds [14]. This problem is proposed to be solved by modernizing the drum design. The hexagonal steel rods (3) on the threshing surface (2) of the drum (1) in Figure 1 were outfitted with triangular transverse grooves (4).

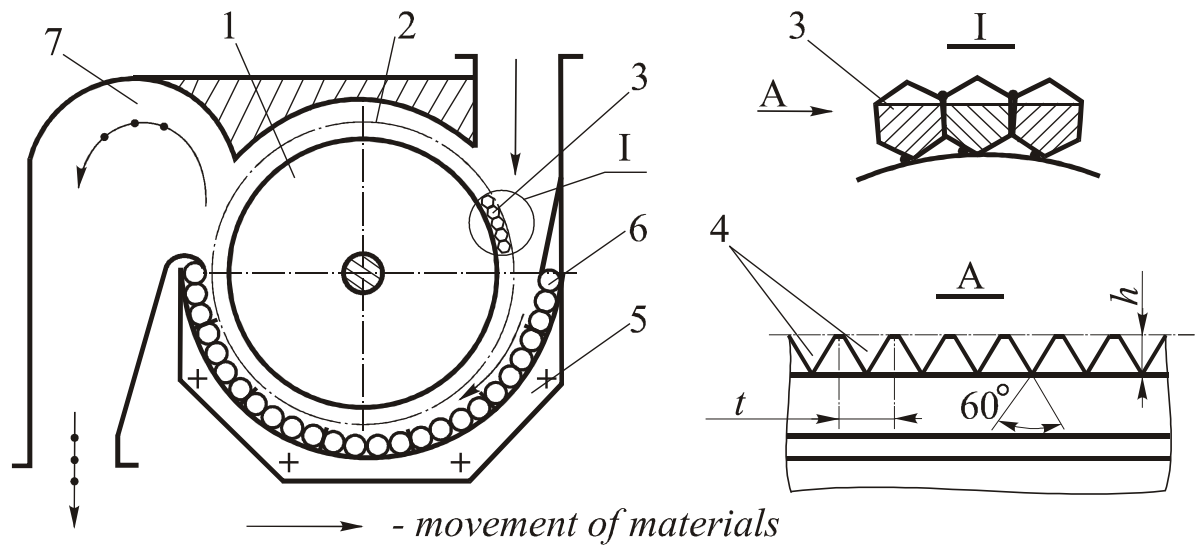

Fig. 1. CS-0.2 clover thresher and scarifier diagram: 1 - drum; 2 - threshing surface of the drum; 3 - hexagonal steel rods; 4 - transverse grooves; 5 - deck; 6 - cylindrical steel rods; 7 - outlet nozzle 
The profile is a triangle with its base on the outer drum surface [15]. The transverse grooves enlarge the seed-thresher interface area, while their sharpened edges improve threshing and scarification performance. Besides, the grooves widen towards the outer drum surface so that threshed material could exit them freely in the unloading bay; this reduces the risk of seed crushing or groove clogging when processing wet hulls. At the same time, sharp edges of the grooves can increase seed crushing.

The goal hereof was to test how such transverse grooves and the drum rotation speed could affect the legume seed threshing and scarification performance.

\section{Materials and Methods}

The thresher-scarifier functions as follows. Clover hulls or hard legume seeds are fed manually or by any lifting mechanism to the gap between the drum (1) and the deck (5). As the drum (1) rotates, the solid awning (entgranner) surface captures clover hulls and drags along the over surface of the deck (5), whereby the compression and the friction thresh the seeds out of hulls. Threshed material is fed by inertia to the outlet nozzle (7) and thus leaves the unit.

When scarifying hard legume seeds, the material travels as described above. As the drum (1) rotates, the awning surface throws the seeds towards the oval surface of the deck (5). Some seeds slide along the surface, while frontal impact and elasticity make other seeds bounce towards the awning surface of the drum, interface it, and repeat the process. This surface-deck-seed interaction damages the solid seed shells and scarifies them.

Steel rods (3) are made of hexagonal rolled steel \#12. The drum has an outer diameter of $300 \mathrm{~mm}$ and an operating length of $200 \mathrm{~mm}$. The transverse grooves (4) have a triangular profile, the depth $h$, and are spaced at $t=6 \mathrm{~mm}$. They widen towards the outer drum surface. The space $t$ is taken from the calculation of the largest number of transverse grooves on the drum, taking into account the maximum length of the eastern galega seed $(4 \mathrm{~mm})$ and the width of the jumpers $(2 \mathrm{~mm})$. The profile of the transverse grooves - an equilateral triangle for the purpose of simplifying experiments has a constant angle of inclination of the faces.

Experiments were designed [16] to test how the drum rotation speed $\mathrm{n}$ and the transverse-groove depth $h$ would affect the performance of threshing red clover hulls for seeds or that of scarifying eastern galega seeds. The hulls had a moisture content of $14 \%$ with $6.0 \%$ coarse culmiferous impurities and $1.5 \%$ loose seeds. Eastern galega seeds met the requirements of GOST R 52325-2005 to seeds used for seed farming. Experiments were carried out at a nominal feed rate: $250 \pm 15 \mathrm{~kg} \cdot \mathrm{h}^{-1}$; the authors implemented a complete second-order Box-Behnken design for two factors: $x_{1}(n)$ and $x_{2}$ (h). The drum rotation speed $\mathrm{n}$ for clover threshing was set to $1,200,1,150$, and 1,700 $\mathrm{min}^{-1}$; For galega scarification, to 600,800 , and $1,000 \mathrm{~min}^{-1}$. The transverse grooves on the threshing surface had the same depth in either process: $h=2.0$, or $4.0 \mathrm{~mm}$. The factors and their variation were adjusted on the basis of exploratory research. Clover threshing performance was measured by the threshing rate $\varepsilon$ $(\%)$ and the crushing rate $d(\%)$. Eastern galega seed scarification performance was measured by the scarification rate $C(\%)$ and the crushing rate $d(\%)$. Experiments were carried out in three repetitions; the gap between the threshing surfaces was 6.0 at the entrance, $3.0 \mathrm{~mm}$ at the exit. Experimental results were processed statistically in STATGRAPHICS + on a PC. Regression analysis models were tested by Fisher's F-test at $p=0.95$; the significance of the regression coefficients was tested by Student's $t$-test (significance level 0.05).

\section{Results and Discussion}

After running the experiments and processing the experimental data, the research team described the clover seed threshing process by two adequate regression analysis models (1) and (2) for the threshing rate and the crushing rate, respectively:

$$
\begin{gathered}
\varepsilon=79.5+13.8 x_{1}-1.1 x_{2}-4.9 x_{1}^{2}+0.9 x_{1} \cdot x_{2}-5.9 x_{2}^{2} \\
d=0.43+2.19 x_{1}-0.95 x_{2}+1.51 x_{1}^{2}-1.06 x_{1} \cdot x_{2}+0.74 x_{2}^{2} .
\end{gathered}
$$

These models are visualized in Figure 2 as curves of the equal threshing rate $\varepsilon$ and crushing rate $d$ values. 
Both metrics were affected the most by the drum rotation speed $n$ (factor $x_{1}$ ). For instance, changing $n$ from 1200 to $1700 \mathrm{~min}^{-1}$ at $h=2.0 \mathrm{~mm}\left(x_{2}=0\right)$ increases the threshing rate $\varepsilon$ from 60.8 to $88.4 \%$, but also raises the crushing rate from the minimum to $4.1 \%$. The groove depth $h\left(x_{2}\right)$ has an ambiguous effect on the threshing performance. In the tested speed range of 1200 to 1700

$\min ^{-1}$, raising $h$ first improved the threshing performance, then worsened it. $\varepsilon$ peaked at medium $h$ values. On the other hand, raising $h$ from 0 to $4.0 \mathrm{~mm}$ at 1450

$\min ^{-1}$ unambiguously reduced the crushing rate $d$. For instance, at $n=1450 \min ^{1}\left(x_{1}=0\right)$ raising $h$ from 0 to $2 \mathrm{~mm}$ reduced $d$ from 2.12 down to $0.43 \%$.

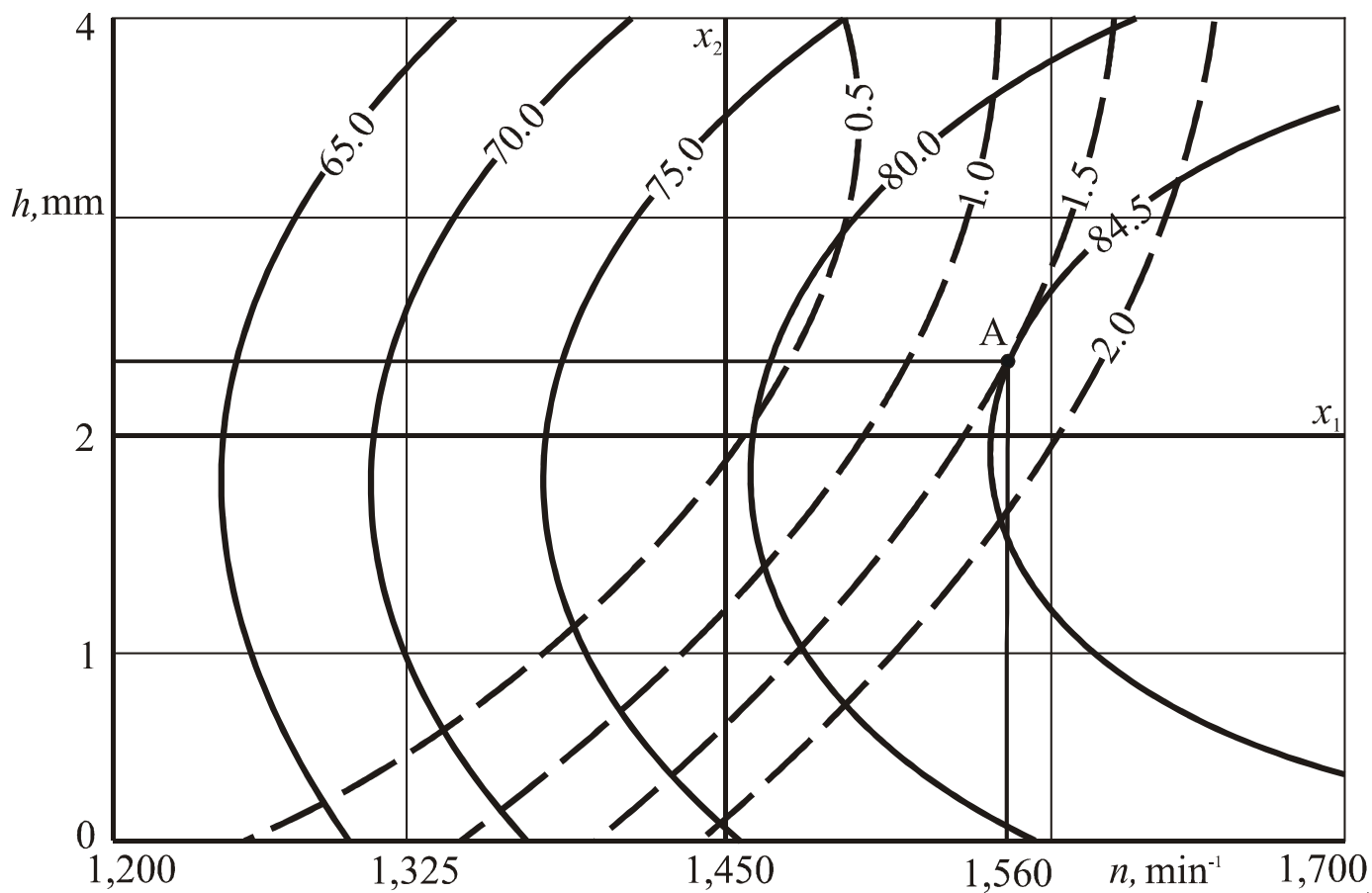

Fig. 2. Curves of equal threshing rates $\varepsilon$ (— $(-)$ and crushing rates $d(-\ldots)$ - - ) as functions of the drum rotation seed $n$ and transverse groove depth $n$ in the threshing surface of the CS-0.2 clover thresher and scarifier

The permissible seed crushing rate is $1.5 \%$, represented by a line that splits the factor space into two. Left of the line, the crushing rate $d$ is in line with the agrotechnical requirements, and the threshing rate $\varepsilon$ decreases farther from the line. At $\mathrm{d}=1.5 \%, \varepsilon$ peaks at $84.5 \%$ at $h=2.4 \mathrm{~mm}$ and $n=1560 \mathrm{~min}^{-1}$ (Point A in Fig. 2).

The optimal threshing rate $\varepsilon=83.8-84.5 \%$ and the acceptable crushing rates $\leq 1.5 \%$ were attained at $h=2.0-2.8 \mathrm{~mm}$ and $n=1,545-1,575 \mathrm{~min}^{-1}$.

Regression analysis models (3) and (4) adequately described the scarification and crushing rates of eastern galega seeds:

$$
\begin{aligned}
C & =99.21+5.73 x_{1}-1.85 x_{2}-4.47 x_{1}{ }^{2+} 2.13 x_{1} x_{2}-1.12 x_{2}^{2} \\
d & =0.84+2.54 x_{1}-1.55 x_{2}+1.80 x_{1}{ }^{2}-1.84 x_{1} x_{2}+0.16 x_{2}^{2} .
\end{aligned}
$$

Figure 3 shows curves of equal scarification rates $C$ and crushing rates $d$ as plotted per equations (3) and (4) in the factor variation domain. $C$ peaked at

$x_{1}=0.58\left(n=915 \mathrm{~min}^{-1}\right)$ and $x_{2}=-0.29(h=1.4 \mathrm{~mm})$. The corresponding $d=3.6 \%$, which is significantly above the agroengineering limit of $1.5 \%$. The shaded area stands for $\mathrm{C} \geq 95 \%$ at $d \leq 1.5 \%$. With the crushing rates being kept within the acceptable limits, the peak scarification rates $C=98.0-99.9 \%$ were attained at $x_{1}=0.20-0.45\left(n=840-890 \mathrm{~min}^{-1}\right)$ and $x_{2}=0.25-0.75(h=2.5-3.5$ $\mathrm{mm})$. It should be noted that the rational rotation frequency of the drum without transverse grooves during scarification is in the range of $900-950 \mathrm{~min}^{-1}$ [14]. The reduction of specific energy consumption during seed scarification is achieved by reducing the rotation frequency of the drum and it is $3-5 \%$. 


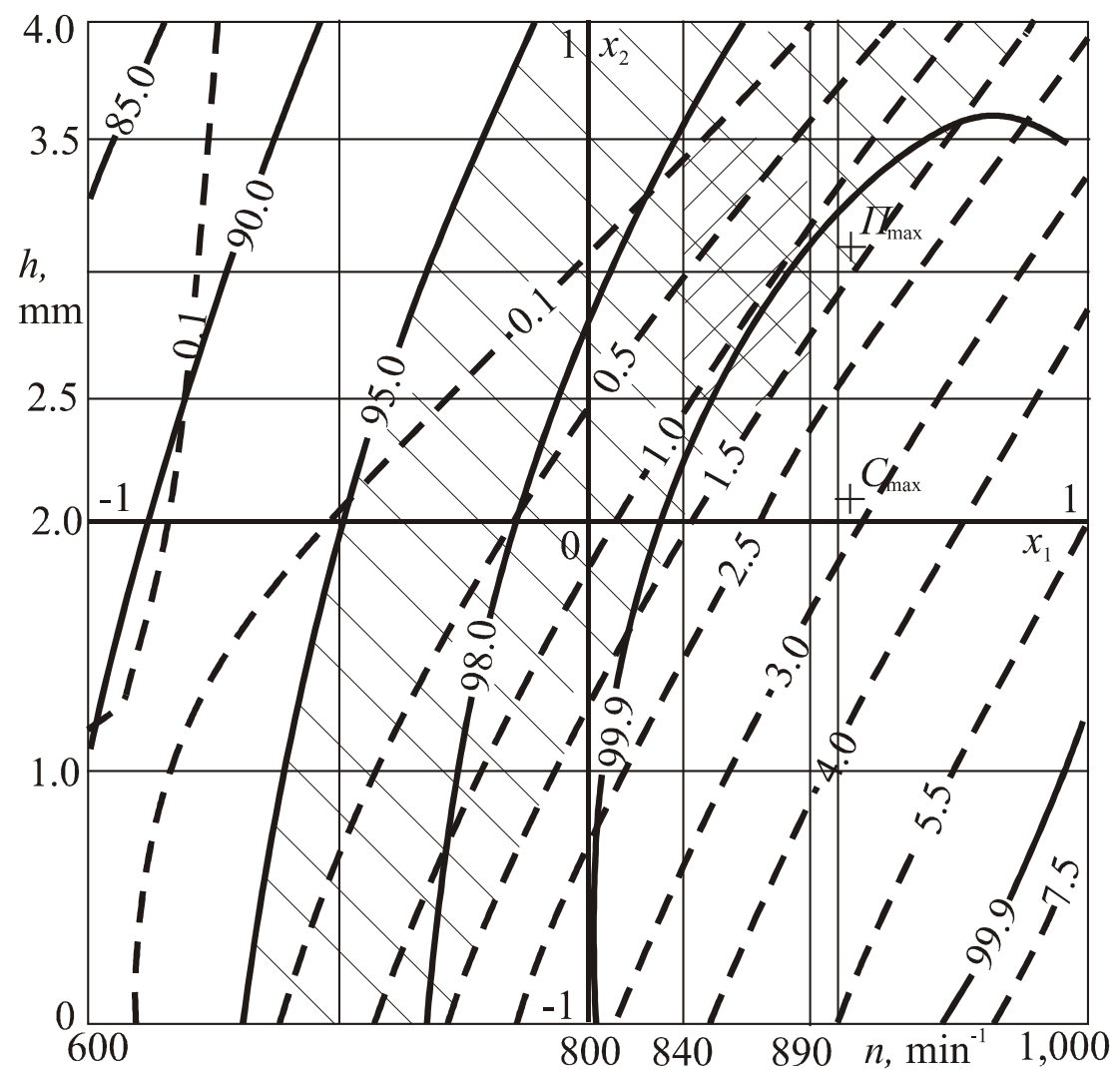

Fig. 3. Curves of equal scarification rates $C$ (—_) and crushing rates $d\left(-\right.$ - $_{-}$-) as functions of the drum rotation seed $n$ and transverse groove depth $n$ in the threshing surface of the CS- 0.2 clover thresher and scarifier

\section{Conclusions}

Transverse grooves on the threshing surface exposed seeds to more intense impact and boosted the scarification and threshing clover seeds for one pass from high humidity hulls for seed performance without changing the deck, i.e. without redesigning the unit. For either process, the optimal groove depth is $2.5 \mathrm{~mm}$; the best drum rotation speed is $1550 \mathrm{~min}^{-1}$ for threshing, $850 \mathrm{~min}^{-1}$ for scarification. The improved drum design makes a more capable machine, reduces specific power consumption and specific costs of seed treatment.

\section{References}

[1] Kimura E., Islam M.A. Seed Scarification Methods and their Use in Forage Legumes. Research Journal of Seed Science, 2012, No 5, pp. 38-50.

[2] Фигурин В.А. Выращивание многолетних трав на корм (The cultivation of perennial grasses to feed). Kirov: Agricultural Research Institute of North-East, 2013. 188 p. (In Russian).

[3] Спиридонов A.M. Многолетние бобовые травы как источник биологического азота в земледелии (Perennial legumes as a source of biological nitrogen in agriculture). Agriculture, 2007, No 3, pp. 14-15. (In Russian).

[4] Золотарев В.Н., Переправо Н.И. Состояние травосеяния и перспективы развития семеноводства многолетних трав в России и Нижневолжском регионе (State of herbage and prospects for development of perennial herb seed production in Russia and the lower Volga region). The proceedings of the lower Volga agrodiversity complex, 2016, No 1, pp. 93-101. (In Russian).

[5] Федоренко В.Ф. Уборка и послеуборочная обработка семян трав (Harvest and post - harvest grass seed processing). Moscow: FSSI "Rosinformagrotekh", 2003. 268 p. (In Russian).

[6] Baes P.O., de Viana M.L., Suhring S. Germination in Prosopis ferox seeds, effects of mechanical, chemical and biological scarificators. J. Arid Environ, 2002. No 1, pp.185-189. 
[7] Martin I., De la Cuadra C. Evaluation of different scarification methods to remove hardseededness in Trifolium subterraneum and Medicago polymorpha accessions of the Spanish base genebank. Seed Sci. Technol., 2004. No 32, pp. 671-681.

[8] Клеверотерка КТ-250 (КТ-250 Clover Thresher) [online] [27.01.2020]. Available at: https: agroserver.ru/b/kleveroterka-kt-250-977803. html.

[9] Клеверотерка К-0,7 Научно-практический центр национальной академии наук Белоруссии по механизации сельского хозяйства (К-0.7 Clover Thresher Agricultural Mechanization Research Center of the Belarussian Academy of Sciences) [online] [25.04.2018]. Available at: http: belagiotech.by agro/mach/k0,7. html.

[10]Машина для вытирания из коробочек семян мелкосемянных культур MBC-05.000 "Воронежсельмаш" (MVS-05.000 Voronezhselmash Unit for Threshing Seeds from Seed Pods) [online] [26.04.2018]. Available at: http: vselmash.ru/zo/newsite/fixed_cleaning_equipm.html /

[11]Машины для селекции, сортоиспытания и первичного семеноводства полевых культур (Machines for selection, variety testing and primary seed production of field crops). Moscow: FSSI "Rosinformagrotekh", 2009. 224 p. (In Russian).

[12]Власов П.А. Скарификация семян многолетних бобовых трав. Скарификаторы инерционного действия (Scarification of seeds of perennial legumes. Inertial action scarifiers). Achievements of science and technology in agriculture, 2006, No 2, pp. 38-39. (In Russian).

[13]Бурков А.И., Симонов М.В., Мокиев В.Ю. Клеверотерка барабанного типа с тангенциальной подачей (Drum type clover thresher with tangential feed). Rural machine operator, 2016, No 4, pp. 12-15. (In Russian).

[14]Бурков А.И., Симонов М.В., Мокиев В.Ю. Результаты исследований вытирающескарифицирующего устройства при вытирании семян из пыжины клевера (Results of researches of the device for extraction and scarification of seeds from clover wad). Agricultural science of European North-East, 2013, No 3, pp. 59-64. (In Russian).

[15]Бурков А.И., Симонов М.В., Мокиев В.Ю. Терочное устройство (Threshing device). Patent of the Russian Federation No 2638844, 2017 (In Russian).

[16] Анисимов Н.П. Об использовании методики планирования эксперимента в соответствие с трехуровневыми планами Бокса-Бенкена (On use of method of experiment planning in compliance with three-level Box-Behnken designs). Bulletin of Masters studies, 2017. No 2-2 (65), pp. 32-36. (In Russian). 